\section{NOTES ON THE CANADIAN NORTH WEST}

THE excursion to the Rocky Mountains, along the Canadian Pacific Railroad, will probably prove a most attractive feature in connection with the British Association meeting this season. Living on the cars for several successive days and nights is a novel experience for most people, and one, it might be supposed, that would prove monotonous; but the alternation of forest, lake, prairie, and mountain scenery, each with its associated peculiarities, will probably prevent the trip becoming at all tedious. Some members of the Association may prefer taking the route through the United States to Winnipeg, but from thence all will proceed through the rich wheat lands of Manitoba, then over the rolling prairies west of Brandon, with their numerous alkali lakes and relatively unproductive soil beyond Moosejaw; through the cattle-ranching district at the eastern base of the Rocky Mountains, and up the winding Bow Valley to the summit-level in the Kicking Horse Pass. Here at Stephen, on the confines of British Columbia, the railway terminates for the present.

On crossing the prairies for the first time, many interesting peculiarities will arrest the attention ; perhaps none so strongly as the general flatness and absence of timber, which as a rule only occurs skirting the rivers, or as a low scrub in certain wet or marshy lands, or in scattered individuals along the dry sand and gravel ridges. These are probably the patches of country that escape the prairie fires, owing to the vegetation being either too damp or too scanty to support a conflagration. Vegetation as a rule is luxuriant, especially on the rich lands, where the grasses grow to a great height. The soil is mostly a rich black loam of variable thickness, accumulating by the annual decay of the grasses or by the ash from the fires. The loam is thickest on those flat lands with clay subsoil that lie south of the Manitoba lakes: in the arid districts of the western sections it becomes very light.

The subsoil is for the most part stratified sand and subangular gravel, which often contain large boulders of gneiss and quartz; it appears to be in a great measure of glacial origin ; but in many places, as in the vicinity of Winnipeg, the subsoil is a stiff brown clay which is probably the filling of an ancient lake: it is seen in the banks of the Red River and Assiniboine. In the high banks of the Saskatchewan at Medicine Hat the clay has more the appearance of a stiff boulder-clay.

A few miles up the River Saskatchewan from Medicine Hat there is an important outcropping of coal ; another seam is exposed on the Bow River near Crowfoot Creek; but the most important is that on the Belly River, where there are active collieries, the fuel being conveyed down the river to Medicine $\mathrm{Hat}$, whence it is distributed along the line of railway. Thesc fuels are lignitic in character, and are considered to be either of later Cretaceous or early Tertiary age. They come to the surface in many localities, and evidently underlie a large portion of the western plains. Adjacent to the eastern face of the Rocky Mountains the strata in which the coals reappear are more indurated and highly inclined, and some of the beds contain silicified wood.

In the section of country between Moosejaw and Medicine Hat alkali lakes are numerous; the smaller ones evaporate during the dry scason, leaving a flat surface covered by a thick, white, glistening deposit: from this district fine specimens of selenite are obtainable. l'robably some of the largest of these bitter lakes are those called the Old Wives Lakes, which lie in a large, sterile depression, on Le Grand Coteau du Missouri, evidently representing the site of a former large inland sea. The fresh-water lakes and marshes, locally numerous along the track, generally teem with wild fowl. In many of them also the tall elevation of reeds, formed by the muskrat, may be seen.
Of other animal life on the plains there is a great absence. However, the so-called "blackbird" or purple crakle (Quiscalus) is locally very abundant; during the early season they keep in pairs, but, on the ripening of the corn, immense flocks of them congregate about it; prairie chicken are also numerous, but of other birds there are very few. Snakes abound in some places; they are constantly to be seen basking in the sun along the railway track. Of mammals the most frequent is the little Gopher or "prairie dog." Almost the only other visible quadrupeds are foxes and a few antelope.

Of the former great numbers of the now practically exterminated buffalo there is abundance of evidence. Their wallowing holes and runs are seen in all directions; the latter, narrow furrow-like tracks, stretch in straight lines across the plains, being most numerous in the vicinity of water. Bleached bones and skeletons, which lie scattered about in great profusion, testify to the wholesale destruction effected, chiefly by the Indians and halfbreeds. On the introduction of modern repeating rifles whole bands of buffaloes were ruthlessly slaughtered, solely for their tongues and skins, and often nothing save the tongues were taken from the carcasses.

This indiscriminate destruction has reduced the Indian of the plains to a state of the most abject poverty and destitution, for formerly most of his wants were supplied by the buffalo; now he is wholly dependent on the Canadian Government, which allows a grant to each individual for his support, amounting in all to about $200,000 l$. per annum. Alcohol is not permitted amongst them, and there is a very heavy penalty for bringing intoxicating liquors into the North-West Territories. Of the various tribes, Sioux, Crees, and Assiniboines are met on the eastern portions of the plains ; the Blackfoot reserve is situated near the Blackfoot crossing on the Bow River, where an Indian supply farm has been established. The Sarsee reserve is near Calgary; and at Morley the Stonys have their reserve; the latter, however, migrate into the mountains early in the season, and spend the summer in hunting; and although game is now very scarce, they are better off in this respect than their brethren of the plains. From these they differ greatly in physique, being shorter and more thick-set. They are more tractable than many of the other tribes, and a mission has been for some time established among them at Morley.

The country of the plains does not appear to be wholly adapted for agricultural purposes ; Manitoba and a great part of Assiniboia are very rich, producing magnificent crops of corn ; but the most fertile belt appears to stretch away from Brandon towards Edmonton, the line of the railway traversing a less fertile district to the south. West of Moosejaw the agricultural prospects are indifferent, and in many cases very poor. About Calgary the season is short, but a good deal of cattle-ranching has been done, and the district is considered well suited for it, although two years ago about 75 per cent. of the imported cattle died; this mortality seems to have been the effect of bringing cattle from lower latitudes late in the season, as, on arriving, they were in such a poor condition that they were unable to bear the winter, which that year set in unusually early, and was particularly severe.

Further north, towards Edmonton, the climate is not considered to be so harsh as about Calgary: this is probably owing to the lower altitude of the mountains permitting the warm Pacific winds to be more bencficial.

Beyond Calgary the railway follows the valley of the Bow River through the district of the Foot Hills for a distance of about fifty miles, when it enters the Rocky Mountain by the Bow Pass at Padmore, or the Gap. Between Calgary and the mountains the character of the country is very different from the prairie districts: the surface is hilly, with patches of pine forest. The strata are more indurated and folded, being often highly inclined. Several well-marked river-terraces can be traced along 
this valley, the uppermost extending far up the Bow Pass. In many districts on the plains the flies are so abundant as to interfere with surveying operations, alighting on the object-glasses in such numbers as to obscure the view. In all the houses the black flies literally cover everything. Earthworms do not occur in the north-west. To the botanist the plains are most attractive, there being an almost endless variety of grasses and pretty little flowers; many of our ordinary garden annuals growing wild over the plains.

To one who crosses the plains by the usual railroad route, the Rocky Mountains are first seen from near Crowfoot Creek, at the distance of about iso miles. They appear as a serrated ridge on the south-western horizon, and numerous patches of snow can very soon be distinguished on them. The entrance to the Bow Pass, by which the mountains are entered, cannot be detected till one is close to the range. It is a comparatively broad winding valley, the direction of the bends being either southwest, across the strike of the strata, or north-west along that strike. The mountains rise precipitously on each side, but the valley itself presents a flat bottom, through which the river winds. This wide level plain, as a rule, is well timbered, the woods extending to a considerable altitude on the mountain sides; but forest fires have reduced the amount of available timber considerably. The trees are mostly either spruce or red fir, and, over the burnt areas, cotton-wood. Along the valley frequent large open untimbered spaces, locally called "parks," bear good pasturage. The removal of the timber from their surface was evidently effected by recurrent fires.

The strata which compose the mountains are regularly disposed, striking north-west and south-east, and having a regular dip to the south-west, which at the outskirts of the range is moderate, but gradually increases till the beds are almost vertical about Castle Mountain. Westwards, in the main divide, they lie more flat. The chief rocks are crystalline magnesian limestones, with calcareous slate, and locally, peculiar siliceous rocks containing opal; amongst the upper beds of the series there are quartzites, grits, and conglomerates.

Near Cascade Mountain an outlier of coal of the same age as the beds on the plains, but much more indurated, rests unconformably on the older rocks, showing that in all probability these Secondary or Tertiary rocks formerly covered most of this Palæozoic area. The older rocks which compose this part of the range are probably of Devonian or Carboniferous age; along the edge of the plains they are cut off by a large fault having a downthrow to the east, which brings the Cretaceous or Tertiary rocks into juxtaposition with them, while to the west they pass under newer strata. River terraces occur along the valley, and near Cascade Park there is a large accumulation of drift, apparently of glacial origin.

Many geologists will probably be disappointed in the Rocky Mountains of the Bow Pass section, for they hardly equal the familiar descriptions of the ranges further south. To the mineralogist, too, they promise but a poor field; the small amount of plication in the strata, and the absence of crystalline rocks, being unfavourable for the development of good mineral specimens. As to the industrial minerals, the resources of the valley have not yet been determined, but it appears that at least one metalliferous belt passes through the highly inclined rocks in the vicinity of Silver City : it bears copper pyrites and glance in veins running transversely to the general direction of the belt. Whether these veins are sufficiently rich, or whether there are large bunches of ore in the belt, has not yet been proved. Argentiferous galena is also known to occur in the grits and quartzites.

The climate of these mountains is very enjoyable in summer-time. During the day it is sometimes rather hot in the valleys, and the flies prove very troublesome, while at night there are often severe frosts. On the hills the temperature is much more equable, there being usually a cool breeze during the day, and at night the air feels warm and balmy. The timber line here is about 6000 feet above sea-level, and although it is only the highest peaks that rise above the line of perpetual snow, yet there are large accumulations of snow on the northern slopes and in many of the valleys, extending some distance below the timber line. On warm days snow-slides may be constantly heard descending with a loud roar. Glacial lakes occur in several of the valleys and cooms.

Fish abound, but they are difficult to catch except in the small rivers and lakes, where, however, they are small.

To the botanist the mountains would probably prove even more attractive than the plains, as there is such variety in the flora according to the altitude. Above the present timber limit vegetation rapidly diminishes, only scattered individuals occurring at a distance above it, one of the most remarkable of these being the forget-menot, bright blue patches of it not uncommonly occur right up alongside the snow banks.

GerRard A. KINAHAN

\section{NATIVE AMERICAN LITERATURE AND ETHNOLUGY'}

UR apology for grouping together so many valuable works on native American literature must be the extraordinary rapidity with which such productions are accumulating. Unless dealt with in this somewhat summary way, they run the risk of not being noticed at all. The great activity recently displayed in this department is largely due to the personal efforts of Dr. Brinton, whose spirited attempt to form a "Library of Aboriginal-American Literature" has already made some progress towards realisation. The first book on our list is practically a reply to those who may be sceptical as to the existence of sufficient materials to warrant such an enterprise. Based on a paper laid before the Congress of Americanists at Copenhagen last year, it takes a summary but comprehensive survey of all the still extant monuments of native literature in the various branches of history, legend, ritual, oratory, poetry, and the drama. In some of these branches the quantity of available matter is considerable. Hundreds of native tales and legends have been committed to writing by the Christian Eskimo of Greenland, and Dr. Heinrich Rink's manuscript collection of their historical traditions fills over two thousand pages. But the quantity of folk-lore and tribal myths floating about in the oral state amongst the Dakotahs, Athabascans, Algonquins, and other North American nations is alone sufficient to supply abundant materials for Dr. Brinton's undertaking. These, however, cannot be properly utilised until the natives have been educated and taught to write their own language, as, for instance, some of the Eskimo, Cherokees, and Iroquois have already learnt to do.

A brilliant result of such education is the "Iroquois Book of Rites," second on our list, which is now printed for the first time from native manuscripts recently brought to light by the editor, Mr. Horatio Hale. In the introduction a curious account is given of these manuscripts. of which there are three extant, two in the Canienga dialect procured at the Iroquois Reserve near Brantford, and one in the Onondaga dialect found at the Reservation near Syracuse, New York. The former are duplicate copies of the "Book of Rites" proper, and one of them appears to be traceable to an original, composed during the latter part of the last century, probably by the

I "Aboriginal American Authors." By Daniel G. Brinton, M.D. (Philadeiphia, 1883.)

"The Iroquois Book of Rites." Edited by Horatio Hale, M.A. (Philadelphia, 1883.)

"The Güegïence : A Comedy Ballet in the Nahuatl-Spanish Dialect of Nicaragua." Edited by D. G. Brinton. (Philadelphia, 188 3 .)

"Sixteenth and Seventeenth Annual Reports of the Peabody Museum of 